\title{
The Development of Seaweed at DI PT. Bantimurung Indah Maros Regency
}

\author{
Yuliana \\ Agricultural Polytechnic Pangkep, Indonesia \\ hj_yuliana10@yahoo.co.id
}

\begin{abstract}
This study aims to know the marketing systems, market shares, sales projection for next 5 years, and marketing prospects of processed seaweed (Semi Refine Carrageenan) at PT. Bantimurung Indah Maros. This study was conducted at PT. Bantimurung Indah Maros located at Dr. Sam Ratulangi Street, Maros Regency, South Sulawesi. This company was one of the branches of Bosowa Group producing processed seaweed. Data collected were processed seaweed production, export realization of processed seaweed, realization of processed seaweed according to types/specification (2003-2007), and industry companies/export-destination countries of processed seaweed at PT. Bantimurung Indah Maros. According to marketing mix analysis of marketing systems of processed seaweed (Semi Refine Carrageenan) of PT. Bantimurung Indah Maros, it was shown that the marketing systems was sales of processed seaweed products (Semi Refine Carrageenan) to industrial companies in the international scale with "Systems Sales" method started by conducting business negotiation with buyer candidates in which it was included the application of all marketing mix variables such as product (sample shipping), price (price offerings), distribution (goods delivery/delivery time) and promotion (local, national and international exhibitions, international seminars and conferences, and internet). According to market shares analysis it was shown that when processed seaweed products (Semi Refine Carrageenan) were converted to dry seaweed (raw material) with sucrose content of $25 \%$, PT. Bantimurung Indah Maros controlled average market shares of 12, 79\% for the last 5 years (2003-2007), and for SRC (TG) products it controlled market shares of 100\% in South Sulawesi. According to prediction analysis of processed seaweed exports (Semi Refine Carrageenan) bulk volume (ton) and value (US\$) by using Least Squares method it was shown that sales volume averaged 305.41 ton/year with value of US\$ -159.548, 8 per year for next 5 years (2008-2012). According to External and Internal Environment analysis (SWOT Analysis it was shown that PT. Bantimurung Indah Maros has much strength, especially in marketing section (company reputation, quality reputation and so on), has many weaknesses (limitations in technology, production facility, and so on), and has many opportunities (prospects of seaweed use, geographical location, and so on).
\end{abstract}

Keyword: Seaweed production, Development, marketing systems, sales projection

\section{Introduction}

Indonesia's contribution to total revenues Semi Refine Carrageenan world in 1992 only about $10 \%$ or about 1000 tons and next year continue to rise until in 1995 the total production of semi-refined carrageenan Indonesia about 2,250 tons. These conditions indicate prospective business opportunities as well as in the procurement of raw materials (Dir. Jen. Perikanan, 1995). Especially for Eastern Indonesia (KTI), until today PT. Bantimurung lndah Maros Bosowa Group under the auspices of Makassar is the only seaweed processing industry that produces semi-refined carrageenan with an installed capacity of 1000 MT per year, and its products are exported to foreign countries. While the potential of seaweed in South Sulawesi during the last 5 years tends to increase. In 1991 the export of seaweed Sulawesi recorded 1,350 tones with a value of US \$ 651,000 and in 1996 to 4,600 tons with a value of US \$ 3.3 million, up an average of $16.45 \%$ per year while the value of exports rose an average of 53,10\% per year. In line with the Local Government Level 1 South Sulawesi, which launched Movement for Export doubled (GRATEKS-2); the export of seaweed is a great opportunity to continue to be developed in addition to shrimp as a main commodity of the fisheries subsector. With the potential of the PT. Bantimurung Indah Maros, then conducted research studies Seaweed Marketing at PT. Bantimurung Indah Maros. 
Formulation of the problem : The formulation of the problem will be raised in this study are as follows: How the marketing system, market share, projected sales, and marketing prospects of processed seaweed (Semi Refine Carrageenan) PT. Bantimurung Indah Maros.

Research Objectives and Purpose: Based on the formulation of the problem, the research objectives are: To determine the marketing system, market share, projected sales, and marketing prospects of processed seaweed (Semi Refine Carrageenan) PT. Bantimurung Indah Maros. While the usefulness of this study is to provide information to the public about the marketing prospects of seaweed in PT. Bantimurung Indah Maros and become a reference for those in need.

\section{Literature Review}

Stanton (1974) suggested "Marketing is a system of overall activities aimed at planning, pricing, promoting and distributing goods and services that satisfy the needs of both the buyers existing and potential buyers". If we examine further the understanding that it is in dasaraya marketing is a system that is related to the planning, pricing, executing promotions, distributing goods and services in order to satisfy the needs and desires of consumers. According to (Mazur, 1968) marketing is an effort on the part of buyers and sellers as well as all activities in the distribution of goods and services between producers and consumers. Soehardi and Sidit (1984) points about marketing as follows: "Marketing is all business activities needed to result in the transfer of property of the goods and services to carry out the physical distribution". From some of these definitions shows that marketing is a process of movement of goods and services to the consumer by using distribution channels in order to facilitate the exchange of goods or services.

Winardi (1981) marketing is the implementation of business activities that direct the flow of objects and services from the producer to the consumer or those who use it. While Kotler (1986) expressed the opinion is a social process that follows: "Marketing is a social process that gives individuals and groups what they need and want, and creating and exchanging products and value with individuals and groups". Further Nitisemito (1977) argues that "Marketing is all the activities / activities to facilitate the flow of goods and services from producers to consumers efficiently with a view to creating effective demand". Based on the opinion of several experts can be concluded that marketing encompasses all human activities that are directed at the effort to satisfy the needs and wants through the exchange process, as we all know that humans have desires and needs are limited, then it encourages them to do things or efforts in order to meet needs that are not limited.

Marketing Mix in a company which is a guideline for companies to have activities that need to be implemented. Kotler (1986) says that in the marketing mix, there are several variables that affect the target market so that the company can run smoothly. According Swastha (1984) suggested that the marketing mix is a combination and 4 variables or activities that are the core of the company's marketing system; products, price structure, promotion and distribution strength. The variables are defined in the marketing mix; Product, Pricing, Distribution, Promotion. The four variables to have a very close relationship with each other to perform a more in-depth analysis of all four of these variables, it allows the company can take an action that leads to kontuinitas companies that will come. Market share of the company is the overall percentage of the company's sales and industrial companies or sales divided by the sales company or the industry as follows:

Market share $=\begin{gathered}\text { Total Sales Company } \\ \text { Total Sales Industry }\end{gathered}$

Definition of market share according to Stanton (1974) "Market share is the ratio of the company's sale to the total industry sales on either and the actual or potential basis" (Market share is the ratio between the company's sales with sales industn good overall on the basis of actual sale or potential profit). Companies that belong to the company into a market leader has always tried to maintain the share, while the company belonging Challenger always trying to find kefemahan-leader of the weaknesses of the company, to be able to seize the market and increase the share market. Inadvertence and weaknesses is a very significant opportunity for the company or rival companies to enter the market or expand the share market, therefore the company must continually monitor market conditions and remain vigilant and trying to increase sales. 


\section{Methodology}

Time and Place Research: This study was conducted in Maros precisely in PT. Bantimurung Indah Maros, as one of seaweed processed (Semi Refine Carrageenan), starting from March to August, 2008.

Data Collection Methods: As a source of data used in this study are: Primary data is data obtained and PT. Bantimurung Indah Maros. And Secondary Data is data obtained from documents such as reports and materials from relevant agencies are closely related to the problems examined.

Data Analysis: The analysis of the data used in the analysis to discuss the seaweed marketing study in PT. Bantimurung Indah Maros is as follows:

1. Analysis of the marketing mix elements include: product, distribution, promotion, and price to determine the marketing system of processed seaweed (Semi refined Carrageenan) PT. Bantimurung Indah Maros. 2. Analysis of market share to determine the market share of processed seaweed (Semi Refine Carrageenan) PT. Bantimurung Indah Maros. The equation used as follows: (Kotler, 1986)

$$
\mathrm{Si}=\frac{\mathrm{Mi}}{\sum \mathrm{Mi}} \text { X 100\% }
$$

where: $\mathrm{Si}=$ Market share of PT. Bantimurung Indah

$\mathrm{Mi}=$ Volume of export PT. Bantimurung Indah

$\Sigma \mathrm{Mi}=$ Total Export Industry

3. Simple Linear Regression Analysis by the least squares method to determine projected sales of processed seaweed (Semi Refine Carrageenan) PT. Bantimurung Indah Maros for 5 years to come. The equation used as benkut (Kotler, 1986):

$$
\begin{array}{cc}
\quad \mathrm{Y}=\mathrm{a}+\mathrm{bX} \\
\text { Where: } \quad \begin{aligned}
\mathrm{X} & =\text { annual Period } \\
\mathrm{Y} & =\text { Total sales }
\end{aligned} \\
\text { whereas: } & \mathrm{a}=\text { constant, } \mathrm{b}=\text { regression coefficient }
\end{array}
$$

4. The internal and external environment analysis (SWOT analysis) which includes Strength (strength), weakness (weakness), Opportunity (opportunities) and Thread (threats), to determine the marketing prospects of processed seaweed (Semi Refine Carrageenan) PT. Bantimurung Indah Maros.

\section{Results and Discussion}

Analysis of Marketing Mix Product: PT. Bantimurung Indah Maros manufacture of processed seaweed (Semi Refine Carrageenan) with the following specifications:

a. ATC (Alkali Treated Cottonii) chip

These products are formed through a process of sorting, soaking, cooking, cutting, drying, and packing.

b. CMPC (Coarse Mesh Powder Cottonii) also called course powder.

This product is a product of reduced size ATC Chip through sogo machine. This machine imported from Japan in 1989.

c. SRC (Semi Refine Carrageenan), consisting of:

-SRC Mesh 60

-SRC Mesh 80

-SRC Mesh 140

Quality Products: Parameter quality seaweed products processed (Semi Refine Carrageenan) PT. Bantimurung Indah Maros is as follows: Moisture (moisture) 10\% max, pH 8-11, syneresis 3\% max, Gell Strength / gel strength of $600 \mathrm{~g} / \mathrm{cm} 2$, viscosity of $100 \mathrm{cps}$, loading 20 MT (20 "), raw materials Eucheuma cottonii and Eucheuma spinosum, Materials Assistant $\mathrm{NaOH}$, sodium Triphosfat, chlorine, and $\mathrm{CH} 3 \mathrm{COOH}$, 
Packaging packed in plastic sacks polypropilene with the inner layer made of polyethylene containing $25 \mathrm{~kg}$ per ball and comes with a manufacturer's label, the product type, net weight and the date of production. While the quality parameters of processed seaweed products (Alkali Treated Cottonii) chips PT. Bantimurung Indah Maros is as follows: Moisture (moisture) 13\% max, $\mathrm{pH}$ 8-11, syneresis 3\% max, Gell Strength / gel strength of $600 \mathrm{~g} / \mathrm{cm} 2$, viscosity of $100 \mathrm{cps}$, swelling 20\% min, Raw Eucheuma cottonii and Eucheuma spinosum, Loading14 MT (20 "), Packaging packed in plastic sacks in polipropilene with layers made of polyethylene containing $35 \mathrm{~kg}$ per ball and is equipped with a factory label, the product type, net weight and the date of production.

Table 1: Production of processed seaweed (Semi Refine Carrageenan) PT. Bantimurung Indah Maros DESCRIPTION

\begin{tabular}{llllllll}
\multirow{2}{*}{ YEAR } & EXPORT & \multicolumn{2}{l}{ PRODUCTS PROCESSED } & & TOTAL & \\
& BBK & ATC & CMPC & SRC & & & \\
& & & & TG & FG & BBK & PROCESSED \\
\hline 2003 & $1,766,840$ & 3,000 & - & 266,000 & & $1,766,840$ & 269,000 \\
2004 & 980,000 & 12,500 & - & 256,000 & & 980,000 & 268,500 \\
2005 & $1,193,600$ & 88,020 & - & 79,000 & & $1,193,600$ & 167,020 \\
2006 & 664,000 & 72,000 & - & 54,000 & 50,000 & 664,000 & 126,000 \\
2007 & 449,000 & 183,000 & - & 80,700 & & 449,000 & 264,000 \\
\hline
\end{tabular}

Source: PT. Bantimurung Indah Maros 2008

Production of raw materials dried seaweed in 2003 was 1.76684 million tons, as much as 269000 tones of processed products with rendamen $25 \%$. In 2004 the dry raw materials as much as 980,000 tons of refined products as much as 268500 tones. In 2005 the dry raw materials increased to 1.1936 million tons, while refined products decreased to 167020 tones. In 2006 the dry raw materials decreased to 664,000 tons, also of processed products decreased to 126,000. In 2007 the dry raw materials experienced a continued decline to 449000 tones, while refined products on the contrary increased to 264,000 tons.

Table 2: Actual Export of Seaweed PT. Bantimurung Indah Maros

\begin{tabular}{lll}
\hline YEARS & VOLUME OF EXPORT $($ Kg ) & VALUE \\
\hline 2003 & $2,035,840$ & $\$ 1.732 .010=14.951 .096 .208$ IDR \\
2004 & $1,248,500$ & $\$ 1.632 .950=14.757 .366 .700$ IDR \\
2005 & $1,360,620$ & $\$ 1.352 .844=12.990 .056 .193$ IDR \\
2006 & 840,000 & $\$ 1.127 .380=10.265 .587 .800$ IDR \\
2007 & 713,000 & $\$ 1.187 .051=10.852 .226 .453$ IDR \\
\hline
\end{tabular}

Source: PT. Bantimurung Indah Maros 2008

Semi processed seaweed exports Refine Carrageenan PT. Bantimurung Indah Maros in 2003 was 2.03584 million tons with a value of US $\$ 1,732,010$. In 2004, exports decreased to 1.2535 million tons with a value of US \$1,632,950, in 2005 exports decreased to 1.36062 million with a value of US \$1,352,844 in 2006, reexports decreased to 840,000 tons with a value of US \$ 1.12738 million. In 2007, exports decreased again to 713000 tones with a value of US $\$ 1,187,051$.

Distribution (Place): Distribution channels of processed seaweed (semi-refined carrageenan) can be seen in Figure 1.

Figure 1: Distribution Channels Seaweed Products Processed (Semi Refine carrageenan) PT. Bantimurung Indah Maros

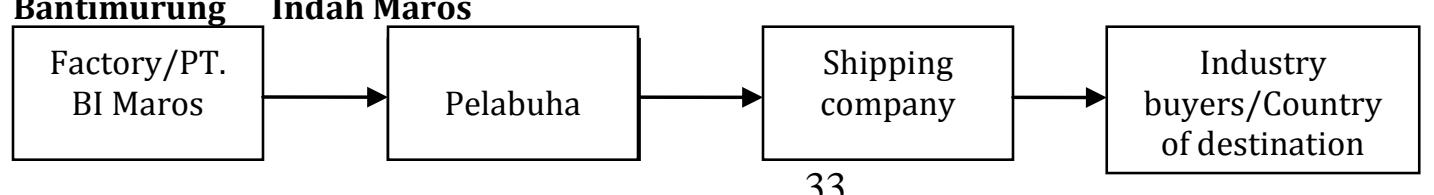


Price (Price): Prices of processed seaweed PT. Bantimurung Indah Maros in 2003 is for BBK products, US \$ 0.545 / kg or Rp. 4,687 / kg, ATC, US \$2.700 / kg or Rp 23220 / kg, SRC (TG), US \$ 3.025 / kg or Rp. 26015 / $\mathrm{kg}$, for products CMPC began in 2000 until now it has never produced again. BBK in 2004 increased to US \$ 0.700 / kg or Rp. 6,090 / kg, ATC also increased to $\$ 3.00$ / kg or Rp. 26,100 / kg, while SRC (TG) decreased, ie, US \$3,000 / $\mathrm{kg}$ or Rp 26,100 / kg. In 2005, BBK decreased to US \$ 0.608 / kg or Rp. 5,776 / kg, ATC increased to US \$3.150 / kg or Rp 29925 / kg. So did the SRC (TG) increased to US \$ 3.410 / kg or Rp. 29925 / kg. 2006 BBK product again decreased at US $\$ 0.500$ / kg or Rp.4.450 / kg, ATC also experienced a decline of US \$2.900 / kg or Rp. 25810 / kg, while the SRC product (TG) increased to US \$3.700 / kg or Rp. 32930 / kg and this year also returned to produce SRC (FG) of US \$4.800 / kg or Rp. 42720 / kg. In 2007 the value of US $\$$ rises so that the price of seaweed products also increased, so did the BBK products also experienced an increase of US \$ 0.700 / kg or Rp. 6,300 / kg, ATC also experienced an increase of US \$3.200 / kg or Rp. 28,800 / kg, while the SRC (TG) products are fixed at US \$3.700 / kg or Rp. 33,300 / kg, and for SRC (FG) there is no production.

Table 3: Price Seaweed PT. Bantimurung Indah Maros

\begin{tabular}{|c|c|c|c|c|c|c|c|c|c|c|c|}
\hline \multirow[t]{3}{*}{ YEARS } & \multicolumn{6}{|c|}{ PRODUCT SPECIFICATIONS } & \multicolumn{5}{|c|}{ RUPIAHS / KG } \\
\hline & \multicolumn{4}{|c|}{$\begin{array}{l}\text { US DOLLAR / KG } \\
\text { BRK }\end{array}$} & & \multirow[t]{2}{*}{ EXCHANGE } & \multirow[t]{2}{*}{ BBK } & \multirow[t]{2}{*}{ ATC } & \multirow[t]{2}{*}{ CMPC } & \multirow{2}{*}{$\begin{array}{l}\text { SRC } \\
\text { TG }\end{array}$} & \multirow[b]{2}{*}{ FG } \\
\hline & & & & TG & FG & & & & & & \\
\hline 2003 & 0,545 & 2,700 & - & 3,025 & - & 8,600 & 4,687 & 23,220 & - & 26,015 & - \\
\hline 2004 & 0,700 & 3,00 & - & 3,000 & - & 8,700 & 6,090 & 26,100 & - & 26,100 & - \\
\hline 2005 & 0,608 & 3,150 & - & 3,410 & - & 9,500 & 5,776 & 29,925 & - & 29,925 & - \\
\hline 2006 & 0,500 & 2,900 & - & 3,700 & 4,800 & 8,900 & 4,450 & 25,810 & - & 32,930 & 42,720 \\
\hline 2007 & 0,700 & 3,200 & - & 3,700 & - & 9,000 & 6,300 & 28,800 & - & 33,300 & - \\
\hline
\end{tabular}

Source: PT. Bantimurung Indah Maros 2008

Promotion: From business negotiations conducted by PT. Bantimurung Indah Maros with the buyer before the sale transaction, the company has done well as promotion through exhibitions both locally, nationally, and internationally, seminars and international conferences. But to expand the market share the company is actively seeking information about industrial company's seaweed world through embassies / trade attaches a State and internet. In 1990 - 1999 the promotion is done through representative offices Bosowa Singapore and Korea, as well as cooperation with company's overseas agent, but once there is a representative office internet removed.

Table 4: Seaweed Industrial Sales in South Sulawesi

\begin{tabular}{llll}
\hline Years & Industry Sales (Ton) & Value (US \$) & \\
\hline 2003 & 8.907 & 3.382 & million \\
2004 & 7.752 & 2.332 & million \\
2005 & 1.013 & 3.094 & million \\
2006 & 15.339 & 8.254 & million \\
2007 & 15.453 & 9.021 & million \\
\hline
\end{tabular}

Data source: Ministry of Industry and Trade 2008

Analysis of Market Share: Sales of the seaweed industry in South Sulawesi in 2003 as much as 8907 tons with a value of US $\$ 3.382 .00,2004$ industry sales declined to 7752 tons with a value of US $\$ 2,332,000$, in 2005 industry sales dropped to 1,013 tons but the value of the dollar increased so that the price of seaweed has increased the amount of US \$3,094,000, in 2006 industry sales greatly increased to 15339 tons with a value of US \$8,254,000. In 2007, industry sales increased again to 15453 tons with a value of US \$9,021,000. 
Table 5: Market Share Seaweed PT. Bantimurung Indah Maros

\begin{tabular}{llll}
\hline Year & Sales Company (Ton) & Industry Sales (Ton) & Market Share (\%) \\
\hline 2003 & $2.035,8$ & 8.907 & 22,86 \\
2004 & $1.248,5$ & 7.752 & 16,10 \\
2005 & $1.360,6$ & 1.013 & 13,4 \\
2006 & 840 & 15.339 & 5,48 \\
2007 & 713 & 15.452 & 4,61 \\
\hline
\end{tabular}

Source: Primary data after being processed 2008

Sales PT. Bantimurung Indah Maros in 2003 was 2035.8 tons, 8907 tons of total industry sales so that the market shares of PT. Bantimurung Indah Maros 22.86\%. In 2004 sales of the company decreased to 1248.5 tons, the industry's sales also decreased to 7752 tones, then the market share of PT. Bantimurung Indah Maros decreased to $16.10 \%$. In 2005 the company's sales increased to 1360.6 tons, while sales of industrial extremely decreased to 1,013 tons, but the market share of PT. Bantimurung Indah Maros decreased to 13 $.4 \%$. In 2006 the company's sales is decreased to 840 tons, while sales of industrial greatly increased to 15 339 tons, so the market share of PT. Bantimurung Indah Maros just 5.48\%. In 2007 the company's sales again decreased, namely 713 tones, while industrial sales continues to rise, namely 15452 , so that the market share of PT. Bantimurung Indah Maros just 4.61\%.

Sales Forecast Analysis: Total seaweed processed (Semi Refine Carrageenan) until the end of this year forecast to as much as 323.36 tons, in 2009 were 17.95 tons, in 2010 greatly reduced (minus) becomes 287.46 ton, in 2011 still declined (minus) becomes -592.87 tons, and in 2012 still declined (minus) becomes 898.28 tons.

Table 6: Forecasting Seaweed Export Processed (Semi Refine Carrageenan) PT. Bantimurung Indah Maros 5 (five) years to come

\begin{tabular}{ll}
\hline Year & Forecast Export (Ton) \\
\hline Y.2008 & $1239,59+(-305,41)(3)=323,36$ \\
Y.2009 & $1239,59+(-305,41)(4)=17,95$ \\
Y.2010 & $1239,59+(-305,41)(5)=-287,46$ \\
Y.2011 & $1239,59+(-305,41)(6)=-592,87$ \\
Y.2012 & $1239,59+(-305,41)(7)=-898,28$ \\
\hline
\end{tabular}

Source: Primary data after processing 2008

Table 7: Forecast Seaweed Export Value Processed (Semi Refine Carrageenan) (US \$) PT. Bantimurung Indah Maros 5 (five) years to come

\begin{tabular}{ll}
\hline Year & forecast for Export (US \$) \\
\hline Y.2008 & $1.406 .447+(-159.548,8)(3)=927.800,6$ \\
Y.2009 & $1.406 .447+(-159.548,8)(4)=768.251,8$ \\
Y.2010 & $1.406 .447+(-159.548,8)(5)=608.703$ \\
Y.2011 & $1.406 .447+(-159.548,8)(6)=449.154,2$ \\
Y.2012 & $1.406 .447+(-159.548,8)(7)=289.605,4$ \\
\hline
\end{tabular}

Source: Primary data after being processed, 2008 
Table 8: Environmental Analysis Internal and External

\begin{tabular}{|c|c|c|c|c|}
\hline No & $\begin{array}{l}\text { Description / Analysi } \\
\text { Internal Environmen } \\
\text { Strength }\end{array}$ & $\begin{array}{l}\text { is } \\
\text { it Weakness }\end{array}$ & $\begin{array}{l}\text { External Environment } \\
\text { Opportunity }\end{array}$ & Thread \\
\hline 1 & Market share & $\begin{array}{l}\text { 1. Limitations } \\
\text { Technology }\end{array}$ & $\begin{array}{l}\text { 1. Prospects usefulness of } \\
\text { seaweed }\end{array}$ & $\begin{array}{l}\text { 1. Intervention } \\
\text { rulers }\end{array}$ \\
\hline 2 & Company Reputation & $\begin{array}{l}\text { 2.Limitations } \\
\text { Production Facility }\end{array}$ & $\begin{array}{l}\text { 2. The geographical } \\
\text { position of Indonesia }\end{array}$ & $\begin{array}{l}\text { international } \\
\text { markets }\end{array}$ \\
\hline 3 & Reputation & $\begin{array}{l}\text { 3. Centralized } \\
\text { Management System }\end{array}$ & $\begin{array}{l}3 . \quad \text { Development } \\
\text { opportunities extract }\end{array}$ & $\begin{array}{l}\text { 2. The threat of } \\
\text { disease }\end{array}$ \\
\hline 4 & $\begin{array}{l}\text { Service } \\
\text { Relationship }\end{array}$ & $\begin{array}{l}\text { (Policy Making by } \\
\text { the } \\
\text { Company) }\end{array}$ & $\begin{array}{l}\text { pure karagihan } \\
\text { 4. The effect of the law of } \\
\text { nature (back to nature) }\end{array}$ & $\begin{array}{l}\text { 3. Business Trend } \\
\text { (Global) } \\
\text { 4. Competitors }\end{array}$ \\
\hline 5 & Principle & $\begin{array}{l}\text { 4.Employee Less } \\
\text { Faithful }\end{array}$ & $\begin{array}{l}\text { 5. Support program } \\
\text { GRATEKS-2 }\end{array}$ & $\begin{array}{l}\text { Increases } \\
\text { 5. Employee Exit / }\end{array}$ \\
\hline 6 & $\begin{array}{ll}\text { Closed } & \text { Systems } \\
\text { Technology } & \text { (Closing }\end{array}$ & $\begin{array}{l}\text { 5. Availability of Funds } \\
\text { / Financial Stability }\end{array}$ & $\begin{array}{l}\text { 6. Reach extensive } \\
\text { marketing }\end{array}$ & $\begin{array}{l}\text { Former } \\
\text { Employees of }\end{array}$ \\
\hline & Dryer) & $\begin{array}{l}\text { 6. Raw Material } \\
\text { Procurement }\end{array}$ & $\begin{array}{l}\text { 7. This year (2008) } \\
\text { Existing }\end{array}$ & PT. BI Maros \\
\hline 7 & $\begin{array}{l}\text { Has Dryers (Open } \\
\text { Dryer) }\end{array}$ & Network Systems & $\begin{array}{lr}\text { Product } & \text { From Buyer / } \\
\begin{array}{l}\text { Buyer) } \\
\text { rulers } \\
\text { markets }\end{array} & \text { Intervention } \\
\end{array}$ & \\
\hline
\end{tabular}

Source: Primary Data after processing 2008

Table 9: Solutions / Troubleshooting Weakness and Thread

\begin{tabular}{|c|c|c|c|}
\hline No & $\begin{array}{l}\text { Description / Solutions } \\
\text { Weakness }\end{array}$ & Thread & Prospects \\
\hline 1 & Mastery of & 1. Research on disease & Bright \\
\hline 2 & Completeness & 2. Mastery of information & \\
\hline 3 & $\begin{array}{l}\text { Decentralized Management System / } \\
\text { Open }\end{array}$ & $\begin{array}{l}\text { technology to monitor } \\
\text { changes in the environment }\end{array}$ & \\
\hline 4 & Increase $\quad$ Employee $\quad$ Benefits & at home and abroad & \\
\hline 5 & $\begin{array}{l}\text { Change / Fixing System Raw Material } \\
\text { Procurement }\end{array}$ & $\begin{array}{l}\text { 3. Maintaining / Improving } \\
\text { Quality }\end{array}$ & \\
\hline 6 & $\begin{array}{l}\text { Fixing the Financial System / Financing } \\
\text { (In Manage Directly By PT. XYZ Maros) }\end{array}$ & & \\
\hline
\end{tabular}

\section{Conclusion and Recommendations}

- Based on the analysis of the marketing mix marketing system processed seaweed (Semi Refine Carrageenan) PT. Bantimurung Indah Maros shows that the marketing system is a selling seaweed products processed (Semi Refine Carrageenan) to industrial companies on an international scale by the method of "Sales System" that begins with business negotiations for a potential buyer, which in business negotiations that has included the implementation of all the variables marketing mix such as product (sample delivery), price (offer price), distribution (delivery of goods / dilatory time) and promotion (exhibitions of local, national, and international, seminars and international conferences, and the Internet).

- Based on market share analysis shows that if the seaweed products processed (Semi Refine Carrageenan) converted into dry seaweed (Raw Material) with rendamen 25\%, PT. Bantimurung Indah Maros market share of $12.79 \%$ on average over the last 5 years (2003-2007), and for products SRC (TG) 100\% market share in South Sulawesi. 
- Based on the analysis of forecast exports of processed seaweed (Semi Refine Carrageenan) Balk volume (tones) and value (US \$) using the least squares method (Least Square) shows that the company is always able to increase sales volume, an average of $-305,41$ tons / year with a value of US $\$-159,548.8$ per year over the next 5 years $(2008-2012)$.

- Based on External and Internal Environment Analysis (SWOT analysis) shows that PT. Bantimurung Indah Maros has various powers (strength), especially in the field of marketing (the company's reputation, a reputation for quality and others), has a weakness - a weakness (limitations of the technology, production facilities, etc.), has a wide range of opportunities (prospect usability seaweed, geographical location, etc.) and have the threat (political intervention of international markets, illness, etc.). By utilizing the best of various powers (strength), overcomes the disadvantages (weakness), take advantage of various opportunities (opportunity) and provide solutions to the threat of the marketing prospect seaweed olahan` (Semi Refine Carrageenan) PT. Bantimurung Indah Maros will be even brighter future.

\section{Recommendations}

- By utilizing the best of various powers (strength), overcoming weakness (weakness), take advantage of various opportunities (opportunity), and provide solutions to the threat (thread), then the prospects for marketing of processed seaweed (Semi Refine Carrageenan) will be even brighter in future, even PT. Maros company XYZ likely to be a pure extract Keraginan (Refine Carrageenan) so as to reduce the burden of imported refined carrageenan is needed in various industrial fields.

- In order to obtain accurate data should be part of the government in this case the Ministry of Industry and Trade as government agencies related to the study authors should be able to provide more specific data in this case involves the export data seaweed according to the type and specifications of the products should be administered separately.

\section{References}

Direktorat Jenderal Perikanan. (1995). News Business Association Seaweed Cultivation and industry Indonesia (BASCII) Jakarta.

Kotler, P. (1986). Marketing Management, Analysis, Planning and Control, Airlangga, Jakarta.

Mazur, P. (1968). Marketing and Social, Challenge of Our Times in A New Measure of Responsibility for Marketing, Ed Kith CO X / Ben. Enif Amarican Marketing, Chicago P. 2.

Nitisemito, A. (1977). Marketing. Ghalia Jakarta Indonesia.

Soehardi \& Sidit. (1984). Practical Marketing, Armoritta Yogyakarta.

Stanton, W. I. (1974). Principles of Marketing. Airlangga. Jakarta.

Swastha, B. D. H. (1984). Principles Marketing, Liberty Yogyakarta.

Winardi. (1981). Management Marketing, New Light, Bandung. 